\title{
STUDENT TEACHERS' READING HABITS AND PREFERENCES
}

\author{
Nana Priajana \\ State University of Malang \\ priajana@gmail.com
}

\begin{abstract}
This study investigates the reading habit and preferences of the Student Teachers studying in their first year at the graduate school in Malang. Although with the advance of technology, media and many factors influencing reading habits and their preferences, the subjects of the study still have good reading habit and positive attitude towards reading activities. To collect the data, the researcher employs the questionnaire with 40 items adapted from a similar research. The items were designed for evaluating reading habits, general attitudes towards reading, and reading preferences of the students. As a result of the study, it is shown that more than half of the students like reading in leisure time and consider it as indispensable part of their lives.
\end{abstract}

Keywords: Reading habits, Preferences, Positive attitude, Student Teacher

In Indonesian Civil Aviation Institutes (henceforth ICAI) particularly pilot and ATC students, the main focus of English instruction is to enable them skilled and proficient in speaking and listening skills (ICAO descriptor in Emery \& Roberts, 2008). It is due to the fact that they shall be able to communicate authentically and spontaneously for flight. However, reading is considered important since it provides comprehensible input for students in acquiring new language. Furthermore, the language they learned is exposed to English for aviation that inevitable related to English for specific purpose. Therefore, they are supposed to introduce to new knowledge, context and specific vocabulary that might impede them to comprehend the text and communication as well. Reading plays an important role in enriching and enlarging readers' knowledge and insights in certain fields with no matters readers read particular texts in their native language (L1) or second/foreign language. In this sense, reading can become effective ways for people to be knowledgeable. Thus, reading is generally viewed as a way of reaching new information and knowledge. It is line with
Ogeyik and Akyay's (2009) notions that reading, which is a long-term habit starting with the very early ages, is the prominent gateway to the knowledge room. Therefore, reading is a crucial process of individual development of capacities in understanding prevailing information of the world.

Have reading habit is not a simply stride for most readers. A habit is a product of learning and reading habits are activities of reading done routinely, consciously and intentionally (Iftanti, 2012). This view shows that readers are required to rehearse their reading to become a good habit. Therefore, to spur the students' reading habit, it is recommended to encourage a desire to read and the texts should be varied and based on the purposes for which the students want to read for instances, books, magazines, newspapers, fiction, non-fiction, texts that inform, texts that entertain, general, specialized, light, or serious (Tamrackitkun, 2010). Thus, by doing that way the students are triggered to have reading habits.

Healthy reading habits are essential for younger generations particularly students to compete in the global marketplaces of the future. Not 
surprisingly, many countries have much attention to reading habits for their people especially in early ages. The importance of reading habit in early ages can equip children with the skills of learning to read and reading to learn to improve their overall capacity for life-long learning and whole-person development. Therefore, reading habits should never be undervalued in order to make people aware of reading is a need as part of their lives.

In the context of education, many factors may influence whether the students have high or low reading habits and motivation. Iftanti (2012) argues that reading motivation of EFL students is influenced with good literacy environment, parents' reading aloud, phenomenal literary works and good reading habits in L1. In this sense, to have good reading habit the students require to have supportive and conducive circumstances either their close environments or reading preferences. As a result, in the sense of continuous and regular progress in education process, the students need to enhance their reading habits to fulfill individual improvement (Ogeyik \& Akyay, 2009).Therefore, reading habits have a very crucial role in the development of the students' competences improvement in the education field.

With the advance of technology and media, however, it may be said that students have less reading time or even no time for reading. The students mostly may spend their leisure times for watching TV, listening to music, playing electronic games, and involving at social networks such as Facebook and Twitters. As a result, the students spend more time for those things than for reading so that their reading preferences are getting less. In connection with student teacher, since they are considered as prospectus teachers, student teachers are supposed to have more time for reading to make them prepared being competent teachers. Therefore, investigating the student teachers' reading habits and preferences will be worth conducting to see whether they are influenced of this condition and if the student teachers have varied reading preferences due to the advance of technology and media.

The aim of this study is to portray the reading habits and preferences of student teachers of graduate program in English Language Teaching and to determine their tendencies and attitude towards reading. From this study, the findings will provide insight of reading attitudes, preferences, and its effects.

Many studies have been conducted to investigate students' reading habits for different level of readers such as, ages, language proficiency, and education (Laksmi, 2007; Ogeyik \& Akyay, 2009; Janthong \& Sripetpun, 2010; Noor, 2011). In this context, reading habits should be taken into consideration important in various situations. Indeed, factors influencing reading habits also need to be well paid attention since they can determine the process of students' reading habits.In addition to that, the readers' preferences or interest also may influence the reading attitudes.

In relation to the students' reading habits and their preferences of reading, there are many notions offered by many researchers. A good reading habit is necessary for a healthy intellectual growth and plays a very crucial role in enabling a person to achieve practical efficiency (Noor, 2011). Furthermore, she describes that an individual's interests are determined to a considerable extent by the amount he will read and the intensity with which he will pursue his reading activity. In her study, she reveals that reading habits are associated with students' gender, age, educational background, academic performance and professional growth. Moreover, Abidin (2011) defines that a good reading habit isan important tool for the development of personalities and mental capacities. He examines the reading habits of Malaysian Chinese students in the current era of technology and electronics. The research findings reveal that the participants prefer the electronic media when reading for leisure but prefer the printed media to pass exams.

Seen from the findings above, reading 
habits of individuals may vary depending on various factors. In general sense, Ogeyik \& Akyay (2009) suggest that choosing reading texts may also depend on those factors. For instance, in education environments, learners as readers are generally directed for reading as a compulsory task and the materials for reading are chosen as the requirement of education process. Therefore, this present research tries to investigate the following questions: 1) How are the reading habits of the student teachers at Graduate Program in ELT? 2) What types of books or texts are the students teachers preferred by the students teacher?

\section{METHOD}

In this study, in order to explore the reading habits and their preferences among student teachers of Graduate Program in English LanguageTeaching, a small survey research method was applied. That is, a questionnaire was given to 26 the first years of Indonesian students studying at State University of Malang, Graduate Program in ELT.

The questionnaire with 40 items adapted by the researcher from a similar research was used for data collection. The items were designed for evaluating reading habits, general attitudes towards reading, and reading preferences of the students. Each item has two choices -yes or no-. The questionnaire was completed bythe students for 10-15 minutes. Of 40 items, 10 items search for general attitudes towards reading, 13 items pertain to the participants' reading preferences, 10 items seek out the effects of reading, and 7 items investigate the negative aspects of reading. The order of the positive and negative expressions was arranged carefully so as not to affect the subjects' objectiveness.

\section{FINDINGS}

To make the data more specific, the researcher analyzed and displayed data taken from the questionnaire separately.
Table 1. General attitude toward reading

\begin{tabular}{|c|c|c|c|c|c|}
\hline \multirow[t]{2}{*}{ No } & \multirow[t]{2}{*}{ Statements } & \multicolumn{2}{|c|}{ Yes } & \multicolumn{2}{|c|}{ No } \\
\hline & & $\mathrm{f}$ & $\%$ & $\mathrm{~F}$ & $\%$ \\
\hline 1 & $\begin{array}{l}\text { I like reading in my leisure } \\
\text { time. }\end{array}$ & 18 & 69 & 8 & 31 \\
\hline 2 & $\begin{array}{l}\text { I like borrowing books } \\
\text { from the library for } \\
\text { reading. }\end{array}$ & 13 & 50 & 13 & 50 \\
\hline 3 & $\begin{array}{l}\text { I like reading only the } \\
\text { recommended books from } \\
\text { the lecturers. }\end{array}$ & 11 & 42 & 15 & 58 \\
\hline 4 & $\begin{array}{l}\text { Formal features of a book } \\
\text { (thickness, font size, } \\
\text { illustrations, etc.) affect my } \\
\text { preference for reading it } \\
\text { or not. }\end{array}$ & 18 & 69 & 8 & 31 \\
\hline 5 & $\begin{array}{l}\text { I usually read the book in } \\
\text { electronic version (E-books) }\end{array}$ & 13 & 50 & 13 & 50 \\
\hline 6 & $\begin{array}{l}\text { I usually find the book I } \\
\text { will read from the library }\end{array}$ & 10 & 38 & 16 & 62 \\
\hline 7 & $\begin{array}{l}\text { I usually buy the book I } \\
\text { will read. }\end{array}$ & 12 & 46 & 14 & 54 \\
\hline 8 & $\begin{array}{l}\text { I initially learn about the } \\
\text { book I will read if my } \\
\text { friends read it. }\end{array}$ & 10 & 38 & 16 & 62 \\
\hline 9 & $\begin{array}{l}\text { I think reading is an } \\
\text { indispensable part of life }\end{array}$ & 21 & 81 & 5 & 19 \\
\hline 10 & $\begin{array}{l}\text { I read a text in the internet } \\
\text { due to its low cost. }\end{array}$ & 20 & 77 & 6 & 23 \\
\hline
\end{tabular}

In Table 1, the findings of the students' general attitude towards reading are displayed. It is clearly seen that from all student, only $69 \%$ students like reading in their leisure time but interestingly reading is considered as indispensable part life $81 \%$ of students. In connection with the books that the students read, a half or $50 \%$ of the students like reading the books from the library but $62 \%$ do not find the books they want from the library. As the alternative ways, $77 \%$ of students prefer reading the text in the internet due to its low cost and $50 \%$ of the students like reading electronic version (E-books) while, only $46 \%$ of students will buy the books for reading. In addition, $42 \%$ students read the books recommended by their lecturers, almost $70 \%$ students consider the features of the books and only $38 \%$ students will read the books as their friends read them.

Table 2. Reading preferences of students

\begin{tabular}{llcccc}
\hline \multirow{2}{*}{ Statements } & \multicolumn{2}{c}{ Yes } & \multicolumn{2}{c}{ No } \\
\cline { 2 - 5 } & $\mathrm{f}$ & $\%$ & $\mathrm{f}$ & $\%$ \\
\hline 11 & $\begin{array}{l}\text { I like reading textbook of } \\
\text { Indonesian authors. }\end{array}$ & 18 & 69 & 8 & 31 \\
\hline 12 & $\begin{array}{l}\text { I like reading textbook of } \\
\text { foreign authors. }\end{array}$ & 25 & 96 & 1 & 4 \\
\hline 13 & $\begin{array}{l}\text { I like reading journals or } \\
\text { research reports. }\end{array}$ & 14 & 54 & 12 & 46 \\
\hline
\end{tabular}




\begin{tabular}{|c|c|c|c|c|c|}
\hline 14 & $\begin{array}{l}\text { I like reading instructional } \\
\text { material. }\end{array}$ & 15 & 58 & 11 & 42 \\
\hline 15 & I like reading newspapers. & 22 & 85 & 4 & 15 \\
\hline 16 & I like reading on-line texts. & 20 & 77 & 6 & 23 \\
\hline 17 & $\begin{array}{l}\text { I read academic articles } \\
\text { because I learn about new } \\
\text { studies in my field. }\end{array}$ & 26 & 100 & 0 & 0 \\
\hline 18 & $\begin{array}{l}\text { I follow at least one monthly/ } \\
\text { weekly culture, art and/or } \\
\text { literature magazine. }\end{array}$ & 9 & 35 & 17 & 65 \\
\hline 19 & $\begin{array}{l}\text { I prefer watching a movie of } \\
\text { a literary book rather than } \\
\text { reading it. }\end{array}$ & 16 & 62 & 10 & 38 \\
\hline 20 & $\begin{array}{l}\text { My favorite literary text is } \\
\text { novel or short story }\end{array}$ & 22 & 85 & 4 & 15 \\
\hline 21 & $\begin{array}{l}\text { My favorite literary text is } \\
\text { poetry }\end{array}$ & 6 & 23 & 20 & 77 \\
\hline 22 & I like reading drama texts & 11 & 42 & 15 & 58 \\
\hline 23 & $\begin{array}{l}\text { like reading books on all } \\
\text { topics }\end{array}$ & 12 & 46 & 14 & 54 \\
\hline
\end{tabular}

Students' reading preferences are presented in Table 2. Almost all students like reading the books of foreign authors $96 \%$ but $69 \%$ students prefer Indonesian authors. And all students $100 \%$ like reading academic articles because they learn something new of the field, 54\% like reading research reports, $58 \%$ student like reading instruction material, newspaper $85 \%$, on-line readers $77 \%$ and they do not follow any types of magazine $65 \%$. In relation to literary works, $60 \%$ students prefer watching movies of a literary book rather than reading it and $85 \%$ students like novel or short story but they do not like poetry $77 \%$ and drama texts $58 \%$. The last, more than half students do not like reading all topics $54 \%$.

\section{Table 3. Effects of reading on students'} performances

\begin{tabular}{llllll}
\hline \multirow{2}{*}{ Statements } & Yes & No & \\
\cline { 2 - 5 } 24 & I read for learning. & 25 & 96 & 1 & 4 \\
\hline 25 & I read for pleasure. & 24 & 92 & 2 & 8 \\
\hline 26 & $\begin{array}{l}\text { Reading makes us gain the } \\
\text { habit of fast reasoning. }\end{array}$ & 73 & 7 & 27 \\
\hline 27 & $\begin{array}{l}\text { Reading is a channel } \\
\text { for gaining real world } \\
\text { knowledge }\end{array}$ & 88 & 3 & 12 \\
\hline 28 & $\begin{array}{l}\text { Ithink'reading' positively } \\
\text { affects my success during } \\
\text { the exams times }\end{array}$ & 96 & 1 & 4 \\
\hline 29 & $\begin{array}{l}\text { Reading enables me to } \\
\text { express my feelings. }\end{array}$ & 77 & 6 & 23 \\
\hline 30 & $\begin{array}{l}\text { Reading develops multiple } \\
\text { reasoning }\end{array}$ & 92 & 2 & 8 \\
\hline 31 & $\begin{array}{l}\text { Reading enhances our } \\
\text { mental capacity }\end{array}$ & 100 & 0 & 0 \\
\hline
\end{tabular}

\begin{tabular}{llllll}
\hline 32 & $\begin{array}{l}\text { Reading develops our } \\
\text { imaginary world }\end{array}$ & 100 & 0 & 0 \\
\hline 33 & $\begin{array}{l}\text { Reading opens the door of } \\
\text { the unknown world }\end{array}$ & 92 & 2 & 8 \\
\hline
\end{tabular}

The findings of reading' effects on students' performance are described in this table. The students, in common, believe that reading can be effective in many aspects of their lives. In this sense, all students (100\%) clearly state that reading can enhance and develop their mental capacity and imaginary world respectively. In addition, $92 \%$ students also consider that reading can give aesthetic pleasure, develop multi reasoning, and open the door of the unknown world as well as $96 \%$ students read for fostering learning and for the success during the exam times. Moreover, $77 \%$ students believe that reading enable them express their feeling and $73 \%$ students can gain the habit of fast reasoning.

Table 4. Negative views of students about reading

\begin{tabular}{|c|c|c|c|c|c|}
\hline \multirow[t]{2}{*}{ No } & \multirow{2}{*}{ Statements } & \multicolumn{2}{|c|}{ Yes } & \multicolumn{2}{|l|}{ No } \\
\hline & & $\mathrm{F}$ & $\%$ & $\mathrm{~F}$ & $\%$ \\
\hline 34 & I don't like reading & 3 & 12 & 23 & 88 \\
\hline 35 & $\begin{array}{l}\text { I find reading as a boring } \\
\text { activity }\end{array}$ & 7 & 27 & 19 & 73 \\
\hline 36 & $\begin{array}{l}\text { I do not have time for } \\
\text { reading }\end{array}$ & 7 & 27 & 19 & 73 \\
\hline 37 & $\begin{array}{l}\text { Due to my heavy workload, } \\
\text { I do not have spare time for } \\
\text { reading on any other topic }\end{array}$ & 14 & 54 & 12 & 46 \\
\hline 38 & $\begin{array}{l}\text { I do not read because I } \\
\text { think the books are too } \\
\text { expensive. }\end{array}$ & 6 & 23 & 20 & 77 \\
\hline 39 & $\begin{array}{l}\text { I do not read because I am } \\
\text { of the opinion that reading } \\
\text { is just a waste of time. }\end{array}$ & 3 & 12 & 23 & 88 \\
\hline 40 & $\begin{array}{l}\text { I find reading as an } \\
\text { unnecessary activity }\end{array}$ & 3 & 12 & 23 & 88 \\
\hline
\end{tabular}

As the students' negative views about reading are examined, it is clearly shown that only $12 \%$ students do not like reading and consider reading as unnecessary and waste of time activities.Moreover, $27 \%$ student state reading as boring activities and do not have time for reading. Differently, due to the students' heavy workload, they do not have spare time for reading any other topics $54 \%$ and only $23 \%$ students do not read because they think the books are too expensive. 


\section{CONCLUSION}

Seen from the overall findings of the study, it reveals that student teachers studying in the first year at graduate program in English Language Teaching, University of Malang have good reading habit and positive attitude towards reading activities. It is shown that more than half of the students like reading in leisure time and consider it as indispensable part of their lives. From the data obtained, it shows the students are quite selective since the students consider the feature of the books before reading them and are not influenced by friends' preferences. However, the students have problems in finding the books from the library since they may not find the books they look for. As the result, they sometimes read the books in electronic version (E-books) and frequently read a text from the internet rather than buy the books. Such findings are similar to former studies conducted by Abidin (2010) and Noor (2011). The former studies revealed that the participants prefer the electronic media and the internet materials. The phenomenon has been more popular since they students can access the desired texts from the internet much easier and simple than search them in the library.

In relation to reading preference of the students, the students like reading the books of foreign authors rather than Indonesian authors. In addition, the students like reading academic articles because of something new of the field, research reports, instruction material, newspaper, and they do not follow any types of magazine. However, In relation to literary works, the students have different kinds of

\section{REFERENCES}

Abidin, Z. (2011). The Reading Habits of Malaysian Chinese University Students. Journal of Studies in Education, 1(1) $p$ 1-13.

Ogeyik, M. \&Akyay, E. (2009). Investigating Reading Habits and Preferences of Student Teachers at Foreign Language literary works such as novel or short story but they do not really like poetry and drama. The last, more than half students do not like reading all topics. From the data obtained, the researcher can conclude that the students tend to read topics that support for their studies or academic purposes rather reading for pleasure.

With regard to the effects of reading on students' performances, the findings show that generally the students believe that reading can be effective in many aspects of their lives. They believe that reading can enhance and develop their mental capacity and imaginary world. In addition, the students also consider that reading can give aesthetic pleasure, develop multi reasoning, and see unknown in the world to foster learning and prepare the exam. Furthermore, students believe that reading enables them to express their feeling and the habit of fast reasoning. Therefore, the students' reading habits are beneficial to develop individual capacity, to express feeling and pleasure.

The final aspect of this study is related to the negative views of the students towards reading. The surveyed data show that most students do not show negative response on reading habits. Differently, due to the students' heavy workload, they do not have spare time for reading and the students do not read because they think the books are too expensive.

Departments. The International Journal of Language Society and Culture. Issue $8,72-80$.

Laksmi. (2007). The Effectiveness of Reading Habit Promotion in Public Libraries of DKI Jakarta Province.ICOLIS 2007, Kuala Lumpur: LISU, FCSIT, 2007: pp 
165-172.

Iftanti, Erna. (2012). Factors Contributing to the Development of the EFLStudents' Good English Reading Habits.Dissertation, English Language Education, Graduate Program. State University of Malang

Janthong, J. \& Sripetpun, W. (2010).English Reading Comprehension and Reading Habit Improvement: Use of Questioning Technique. The 2nd International Conference on Humanities and Social Sciences April 10th, 2010 Faculty of Liberal Arts, Prince of Songkla University

Noor, M. (2011). Reading Habits and Preferences of EFL Post Graduates: A Case Study. CONAPLINJOURNAL Indonesian Journal of Applied Linguistics, Vol. I No. 1

Tamrackitkun, K. 2010. Extensive Reading: an Empirical Study of its Effects on EFL Thai Students' Reading Comprehension, Reading Fluency and Attitudes. Dissertation School of Languages University of Salford, Salford, UK. 